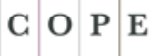

Member since 2018 JM13714
Spotkania / dyskusje / polemiki

Lisa M. Tillmann*

\title{
Mother Mentor: A Tribute to Carolyn Ellis ${ }^{1}$
}

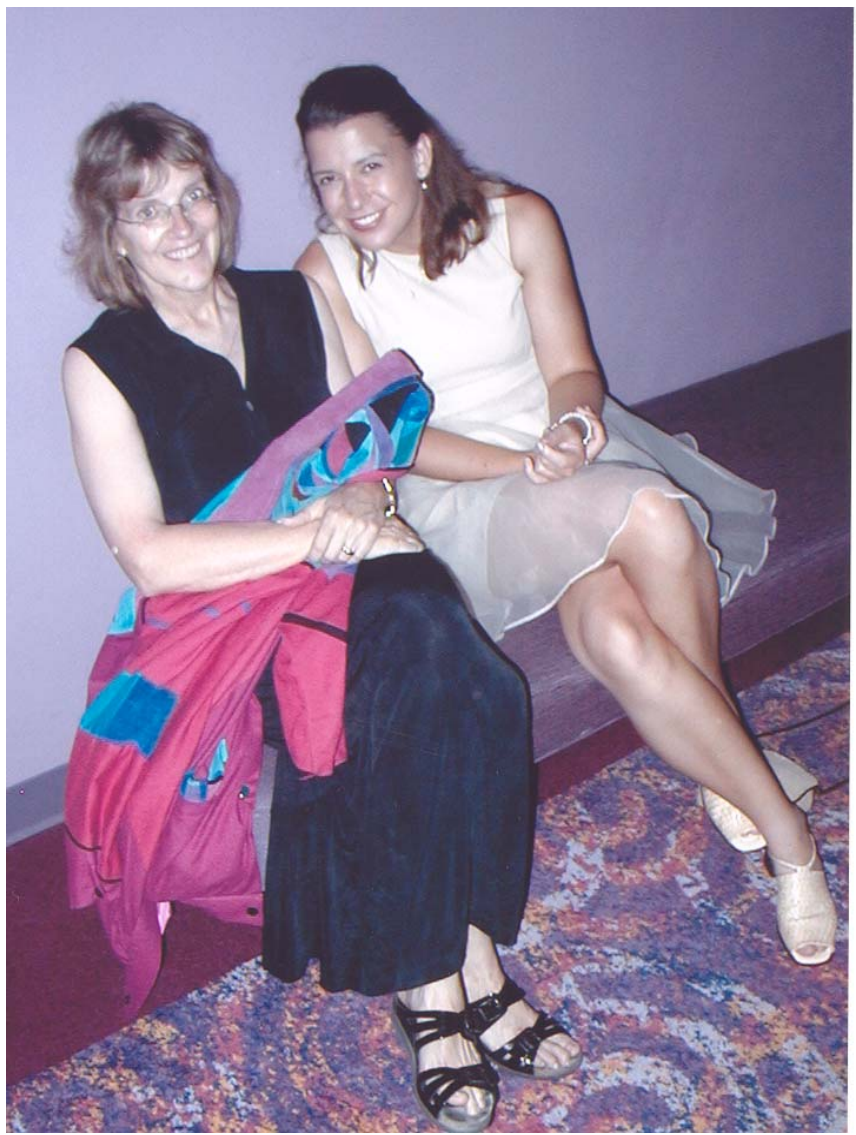

* Department of Critical Media \& Cultural Studies Rollins College.

${ }^{1}$ This work was originally published as: Tillmann-Healy L. M. (2003) Mother Mentor: A Tribute to Carolyn Ellis, "American Communication Journal," 6 (2). Reprinted by permission of the American Communication Association. 
It was 1993, early November.

Not yet an ethnographer,

but still, I remember

my other mentor,

Art Bochner,

said, "Meet my partner,

Carolyn."

CDB Pizzeria,

eating my first fried green tomato ${ }^{1}$

(how prophetic),

I met her.

I had heard rumors.

"She'll open your doors."

"Be prepared to explore."

"You should have known Art before:

contentious, even testy.

We call that period 'B.C.' -

Before Carolyn."

I beheld

her resplendent ensemble:

native print, vivid colors,

crowned at the ears

by gemstone and silver.

Her face, framed by soft curls, was more supple and maternal than I expected.

She took my hand in hers, a touch that soothed and foreshadowed. "I feel like I know you," said Carolyn.

I would learn later

that in her voice, she heard stigma, ${ }^{2}$

${ }^{1}$ Avnet, Kerner, Avnet (1991).

2 Ellis (1998).

NAUKI O WYCHOWANIU. STUDIA INTERDYSCYPLINARNE 
to me an enigma,

for I heard possibility, vulnerability,

Investigating Subjectivity, ${ }^{3}$

a new vocabulary

of narrativity, reflexivity,

autoethnography,

feminist methodology,

emotional sociology, 4

and Composing Ethnography. ${ }^{5}$

Drawn by the magnetic force

of this voice

I enrolled

in a succession of her courses.

For Narratives of Illness,

we listened, bore witness

as stories

poured

forth

like blood:

rivulets of pain

signifying

life

and self-consciousness.

In Qualitative Methods, she taught us

to experience

the allegiance

of the personal and political, the individual and cultural, the affective and rational, the therapeutic and intellectual.

As we surrendered

to her tenderness,

she rendered

${ }^{3}$ Ellis, Flaherty (1992).

${ }^{4}$ Ellis (1991a).

${ }^{5}$ Bochner, Ellis (1996). 
the severed

blurred fiction and fact,

intact,

revealed kindness

as transgressive act.

A class called Emotions,

came with Lamott's Operating Instructions. ${ }^{6}$

This set in motion

systematic sociological introspection, ${ }^{7}$

the exploration

of Franck's Separation, ${ }^{8}$

and the never Final Negotiations. ${ }^{9}$

Disclosing our hunger,

exposing anger's heat, we searched

for closure

and the peace

of Mercy Street. ${ }^{10}$

But it wasn't all

so serious. In her world,

affliction is poetic, even humorous.

"Dr. Denzin," she'd greet,

"how I'd like you to meet," (not John and Jennifer,

Christine, and me) but "Heart Attack, Hodgkins,

and Bulimia Squared."

We learned to wear

the identities we most feared

from Carolyn.

In thick descriptions

of mothers

brothers,

lovers

and Others,

${ }^{6}$ Lamott (1993).

${ }^{7}$ Ellis (1991b).

${ }^{8}$ Franck (1993).

${ }^{9}$ Ellis (1995).

10 Sexton (1994).

NAUKI O WYCHOWANIU. STUDIA INTERDYSCYPLINARNE 
loves beginning,

lives ending,

hearts breaking

and mending, her words testify that indeed,

"There are survivors."11

She has her critics

who sling their polemics:

"Soft, touchy feely."

"Promotes victimology."

"Who stole sociology?"

But beware those who wage

discursive war on this sage.

They emerge in her pages, crusty barnacles

by Carolyn Ellis.

for the next article

So many layers:

teacher,

nurturer,

caretaker,

lover of my second father,

garden sower,

dance master,

prolific writer,

fire walker,

gentle spirit,

tender of secrets,

mother mentor:

Carolyn Ellis.

\section{References}

Avnet J. (producer), Kerner J. (producer), Avnet J. (director) (1991) Fried Green Tomatoes [motion picture], United States, Universal Pictures.

Bochner A. P., Ellis C. (Eds.) (1996) Composing Ethnography: Alternative Forms of Qualitative Writing, Walnut Creek, CA, AltaMira Press.

${ }^{11}$ Ellis (1993). 
Ellis C. (1991a) Emotional Sociology in: Studies in Symbolic Interaction: A Research Annual, N. K. Denzin (Ed.), vol. 12, Greenwich, CT, JAI: 123-145.

Ellis C. (1991b) Sociological Introspection and Emotional Experience, "Symbolic Interaction," 14: 23-50.

Ellis C. (1993) "There Are Survivors": Telling a Story of Sudden Death, "Sociological Quarterly," 34: 711-730.

Ellis C. (1995) Final Negotiations: A Story of Love, Loss, and Chronic Illness, Philadelphia, Temple University Press.

Ellis C. (1998) I Hate My Voice, “Sociological Quarterly," 39: 517-537.

Ellis C., Flaherty M. G. (Eds.) (1992) Investigating Subjectivity: Research on Lived Experience, Newbury Park, CA, Sage.

Franck D. (1993) Separation, New York, Alfred A. Knopf.

Lamott A. (1993) Operating Instructions: A Journal of My Son's First Year, New York, Pantheon Books.

Sexton L. G. (1994) Searching for Mercy Street: My Journey Back to My Mother, Anne Sexton, Boston, Little, Brown and Company. 